\title{
Linkages between Economic Growth, Poverty and Environmental Quality in Indonesia
}

\author{
Bagus Sumargo'), Rahadita Nur Haida ${ }^{2)}$ \\ ${ }^{1)}$ Faculty of Mathematics and Natural Science, Universitas Negeri Jakarta \\ ${ }^{2)}$ Statistics Indonesia \\ Corresponding Author: bagussumargo63@gmail.com
}

Recieved: June 2019 | Revised: March 2020 | Accepted: March 2020

\begin{abstract}
The biggest obstacle to sustainable development in Indonesia is due to social-environmental factors. The objective of this study is to identify lever variables in the intended socio-environmental factors through dimensional analysis in sustainable development. By using the path analysis methods and secondary data on economic growth, the number of poor people and an index of environmental quality in Indonesia, 2016, it can be proven that poverty has a direct negative effect on environmental quality. This makes it possible to occur in the rural poverty typology because their needs for life depend on natural resources. Therefore, poverty reduction policies should be prioritized in reducing the number of poor people in rural areas.
\end{abstract}

Keywords: sustainable development dimensions, path analysis method, poverty-environmental quality

JEL classification: 015 ; O44

How to Cite: Sumargo B., Haida R., N. (2020). Linkages between Economic Growth, Poverty and Environmental Quality in Indonesia. Jurnal Ekonomi Pembangunan: Kajian Masalah Ekonomi dan Pembangunan, 21(1). 47-59. doi:https://doi.org/10.23917/jep.v21i1.8262

DOI: https://doi.org/10.23917/jep.v21i1.8262

\section{Introduction}

Shift in economic structure in Indonesia since 1991 from the agricultural to the industrial sector had an impact on the success of economic development. The consequences of this transformation are the differences in labor income between the agricultural and industrial sectors, which led to poverty, especially in rural areas and environmental quality problems. To present, there have been no scientific studies that prove the existence of a significant influence between poverty and environmental quality based on the concept of sustainable development.

Environmental quality is indicated by the Environmental Quality Index (EQI), which includes an index of air quality, water, and land cover. During the period 2013 to 2016, when there was a slowdownin economicgrowth, environmental quality showed improved value. However, when economic growth accelerates, the quality of the environment decreases. The results of research in some poor and developing countries showed that environmental quality decreased along with the increase of economic growth. Another problem with economic and environmental development is poverty (Oktavilia et al., 2018). The enhancement of developing countries is desired to alleviate poverty and achieve social equity, but it increases their environmental impact (Scherer et al., 2018).

This is consistent across several studies relating to the relationship between economic growth and declining environmental quality in 
poor and developing countries (Everett et al., 2010). This inversely proportional development shows that the development in the economic field is not followed by improvements in the quality of the environment in Indonesia which ultimately reduces the quality of the environment in 2016 (Ministry of Environment and Forestry, 2017). 2017). The non-significant relationship between economic growth and environmental pollution indicates the non-existence of EKC in West Africa (Adu \& Denkyirah, 2017).

EQI, with a declining rate, could threaten the sustainability of development itself. Sustainable Development is a development that must be able to accommodate a balance between economic, social and environmental development. Economic development is expected to improve people's welfare. However, the development of the economy in Indonesia is not yet in line with social and environmental sectors development, which means there are gaps in achieving all three of them. The gap in economic and environmental development can be seen from the data of economic growth and EQI from 2015 to 2016. In 2015, economic growth was valued at 4.88 percent, and in 2016 economic growth increased to 5.03 percent. It implies that economic growth accelerated from 2015 to 2016 . On the other hand, the quality of the environment declined as indicated by the EQI data of 68.23 in 2015 and 65.73 in 2016 , respectively.

In 2016 Indonesia's environmental quality differed between provinces, meaning that the quality of the environment was not evenly distributed, especially between the western and eastern regions. In general, the western part of Indonesia has worse environmental quality than eastern Indonesia. Some provinces in western Indonesia have alert and bad environmental qualities. While Papua and West Papua have very good environmental quality, they are viewed from the development of the economy, inter-regions in Indonesia also experiencing inequality. This can be seen from the contribution of Gross Regional Domestic Product (GRDP) of Sumatera and Java (Jawa)-Bali Islands, which are much higher than in other regions. Based on Statistics Indonesia data in 2016, the contribution of Java and Bali to Indonesia's GDP reached 60 percent. They were then followed by Sumatra Island, which has a contribution of 21 percent. Meanwhile, in the eastern provinces of Indonesia, the overall contribution to GDP is only 19 percent.

Furthermore, the development of social fields, especially the efforts to reduce poverty in Indonesia, also has not been achieved in accordance with the government's development goals for 2016. The 2015-2019 National Medium-Term Development Plan (RPJMN) targets the poverty rate in 2016 to be 9 to 10 percent. This is stated in Article 41 of Law No.14 of 2015 concerning the State Budget 2016 (Ministry of Finance, 2018). Whereas in fact, the percentage of poor people in Indonesia reached 10.9 percent or 28 million people in 2016 (Statistics Indonesia, 2017). In addition to the imbalance between the quality of the environment and GRDP contribution, the poor population is not evenly distributed between the western and eastern regions of Indonesia. The percentage of poor people in the western region of Indonesia ranges from 3-17 percent of the total population of the western region. Meanwhile, for eastern Indonesia, the percentage of poor people ranges from 4-28 percent of the total eastern population. High economic growth is needed to reduce the number of poor people, on the other hand, economic growth and poverty can worsen and even accelerate the process of decreasing environmental quality through extractive use of natural resources and less eco-friendly ways. the economic growth, environmental quality and globalization affect human quality in Indonesia positively, while poverty and population density affect negatively (Oktavilia et al., 2018).

The impact on human development is important to reduce environmental degradation and can play a positive role in achieving sustainable development (Costantini, 2006). Relationship of economic growth and declining environmental quality in poor and developing countries (Everett et al., 2010). Improved 
economic activity on a larger scale will lead to an increase in environmental damage. This is due to excessive resource exploration and unsustainable industrialization (Copeland \& Taylor, 2004). For these reasons, this study aims to find out whether the economic growth achieved by Indonesia in 2016 can reduce poverty and whether the economic growth can also preserve the environmental quality directly with efforts of sustainable development in Indonesia. Therefore, the purpose of this study is to find out the general description of economic growth, poverty, and environmental quality in Indonesia in 2016 and identify the effects of economic growth on poverty, poverty on environmental quality, and economic growth on environmental quality both directly and indirectly through poverty in Indonesia in 2016. The results of this study indicate that changes in the number of a poor population have a negative and significant effect on environmental quality at a significance level of 5 percent. This means that an increase in the number of poor people will reduce the quality of the environment. The negative relationship between poverty and environmental quality is in accordance with the Common Property Resource theory that poor people have a large dependence on natural resources for their survival, resulting in deteriorating environmental quality due to environmental management that does not pay attention to sustainability. In other word, the development of poorer countries is desired to alleviate poverty and achieve social equity, but it increases their environmental impacts.

The negative impact of poverty on the environment in the form of decreasing environmental quality occurs both in urban and rural areas. The increasing population in urban areas is often not balanced by providing decent settlements, for example, DKI Jakarta province. Low-income people have limited ability to have decent settlements, forcing them to live in marginal areas, such as river banks (Pratomo \& Sumargo, 2017). The increasing number of poor people in urban areas makes slums more crowded and tight (Sumargo \& Novalia, 2018). The number of slum settlements by poor people causes the river to become a place for the human waste disposal so that it pollutes the river body with pollutants such as total phosphate, fecal coli, and total coliform that comes from human waste itself. This situation is exacerbated by the disposal of residues or household waste directly directed to the river. This is one of the causes of why DKI Jakarta province has the lowest environmental quality index, with the lowest river water quality (Ministry of Environment and Forestry, 2017).

The indigent people in rural areas depend on natural resources and the environment to survive without knowing the consequences of exploiting these natural resources (Klasen, 2000)the correlation is much weaker among the worst-off South Africans. In addition, the two measures differ considerably in the impact of race, headship, location (urban, rural. The majority of the poor who depend on the environment as their livelihood is evidenced by Susenas data in 2016, amounting to $47.06 \%$ of the poor population aged ten years and over with no working status, $30.37 \%$ as workers in the agricultural sector, and the rest in the field sector another business. For example, most of the poor who use natural resources and the environment for livelihood is agriculture. According to Hastuti (2007), slash-and-burn agricultural practices in Indonesia occur due to poverty. Acquisition or expropriation of agricultural land causes the ratio of land area to a population to be lower so that the intensity of land cultivation is higher and leads to acceleration and exacerbates environmental damage. Then another example of the practice of the livelihoods of the poor that can damage the environment is people's mining activities. Small-scale mining actors are poor people who have limited capital and expertise, this leads to the handling of processing waste that has not been good so that it causes land and river 
pollution (Sahputra, 2014).

Research that is relevant to this study by Hajiji (2010) who explained that economic growth in Riau was able to reduce poverty but also increase income inequality. The increase in income inequality became an obstacle or reduced the effectiveness of economic growth in alleviating poverty. In addition, a prior study by Dariah (2007) in West Java showed that environmental degradation as measured by critical land area, $\mathrm{CO} 2$ emissions, Total Overture Solids, and Biological Oxygen demand increases as economic growth and the increase in poverty.

\section{Research Method}

\subsection{Theoretical Study}

Based on the previous explanation, there is no scientific research that links simultaneous linkages between the three dimensions of sustainable development. Thus, this article looks at a path analysis method to find environmental quality levers in the concept of sustainable development. Sustainable development is a development that can increase the wealth and prosperity of a society in the long run (Rogers et al., 2008). This means that every policy taken to increase current wealth and prosperity must be able to continue into the future, the policies taken at this time must also be able to improve living standards for future generations. In implementing sustainable development, a balance between economic, social and environmental development is needed. These three dimensions are referred to as the triple bottom line used to measure the success of a development program (Rogers et al., 2008). The major development problem in Indonesia are the low and inequality economic growth (Zia \& Prasetyo, 2018). The concept of sustainable development is the result of the growing awareness of the global links between mounting environmental problems, socio-economic issues to do with poverty and inequality and concerns about a healthy future for humanity. It strongly links environmental and socio-economic issues
(Hopwood et al., 2005). The development of poorer countries is desired to alleviate poverty and achieve social equity, but it increases their environmental impacts (Scherer et al., 2018).

Economic development is a step to increase income while maintaining capital stock to remain constant or increase. One of the indicators to see economic development is economic growth. Development is said to be successful if economic growth is high enough (Budiman, 1995). The development of the social sector itself means maintaining the stability of the system, one of the goals being the decline in poverty. Environmental development is to maintain the resilience and robustness of biological and physical systems of the environment that can be measured by its quality. Economic growth is expected to be able to encourage the development of the social sector, namely improving the welfare of people in various layers, especially in the poor population group with a decrease in poverty (pro-poor). Economic growth has a direct influence on poverty by means of real GDP growth followed by a decline in poverty (Piotrowska, 2016; Ravallion \& Chen, 2003).

Previously, Sustainable economic development was directly related to the improvement of living standards of the poor (Rogers et al., 2008). In the context of economic and social development, like increasing the wealth and welfare of the people through economic growth, it is necessary to manage sustainable resources, including the environment. In the Solow economic growth model, also explained that economic growth is not only influenced by labor and capital but also influenced by natural and environmental resources (Siregar, 2010). Therefore, the quality of the environment must be ensured to be sustainable so that development efforts can continue continuously, which means proenvironment economic growth

EQI, which is one indicator of environmental quality, consists of three aspects, namely air quality, water quality, and land cover with indicators and parameters shown in Table 1. 
Table 1. Indicators and Parameters of EQI

\begin{tabular}{|c|c|c|c|}
\hline No. & Indicators & Parameters & Weight \\
\hline 1. & River water quality & $\begin{array}{l}\text { Total Suspended Solid (TSS), } \\
\text { Dissolved Oxygen (DO), } \\
\text { Biological Oxygen Demand (BOD), } \\
\text { Chemical Oxygen Demand (COD), Total } \\
\text { Phosphate, Fecal Coli, Total Coliform }\end{array}$ & $30 \%$ \\
\hline 2. & Air quality & $\begin{array}{l}\mathrm{SO}_{2} \\
\mathrm{NO}_{2}\end{array}$ & $30 \%$ \\
\hline 3. & Land cover quality & $\begin{array}{l}\text { Area of Land Cover and Vegetation } \\
\text { Dynamics }\end{array}$ & $40 \%$ \\
\hline
\end{tabular}

Source: Ministry of Environment and Forestry (2017)

\subsection{Path Analysis}

This study uses secondary data in the form of Gross Regional Domestic Product (GRDP) at 2010 constant market prices in 2015 and 2016, and the number of poor people in 2016 sourced from the BPS-Statistics Indonesia for 33 provinces. Also, the 2016 Environmental Quality Index (EQI) data from the Ministry of Environment and Forestry (MEF). Inference analysis used in this study is path analysis with structural equation models as follows:

$\operatorname{LnP} 0_{i}=\rho_{Y_{1} X} P D R B_{-} G_{i}+\varepsilon_{1}$

$I K L H_{i}=\rho_{Y_{2} X} P D R B_{-} G_{i}+\rho_{Y_{2} Y_{1}} \operatorname{LnP} 0_{i}+\varepsilon_{2}$

where:

$L n \mathrm{PO}_{i} \quad$ : the growth of poor population number in province $\mathrm{i}$

PDRB_G $G_{i}$ : the economic growth in province i

$I K L H_{i} \quad$ : the environmental quality in province i

$\rho_{Y_{I} X} \quad$ : path coefficient between $\mathrm{Y}_{1}$ and $\mathrm{X}$

$\rho_{Y_{2} X} \quad$ : path coefficient between $\mathrm{Y}_{2}$ and $\mathrm{X}$

$\rho_{Y_{2} Y_{1}} \quad$ : path coefficient between $\mathrm{Y}_{2}$ and $\mathrm{Y}_{1}$

$\varepsilon_{1}: 1^{\text {st }}$ structural equation error

$\varepsilon_{2} \quad: 2^{\text {nd }}$ structural equation error

\section{Results and Discussion}

3.1 Results

\subsubsection{General Overview of Economic Growth in Indonesia in 2016}

Indonesia's economic growth rate in 2016 shows a positive value of 5.03 percent, it means that Indonesia's output has increased from 2015 to 2016. Indonesia's economic growth in 2016 showed greater value than economic growth in 2015, meaning that Indonesia's economic growth in 2016 accelerated. The increasing output is one of the reflections that Indonesia's economic development has been successful. The positive economic growth is followed by economic growth in each province.

All provinces in Indonesia experienced an increase in GRDP at 2010 constant market prices from 2015 to 2016, or there was economic growth in each province. The economic growth is ranged from 0.04 percent to 9.98 percent with the East Kalimantan (Kaltim/Kalimantan Timur) as the province with the lowest economic growth and the Central Sulawesi (Sulteng/Sulawesi Tengah) as the highest economic growth province and followed by Papua province. The high economic growth in Central Sulawesi (Sulawesi Tengah) was caused by the high economic growth of the manufacturing sector, which is 35.12 percent and followed by the mining and quarrying sector by 35.08 percent from 2015 (Statistics Indonesia, 2017).

Meanwhile, the high economic growth of Papua Province was supported by the Mining and Quarrying sector. The Mining and Quarrying sector contributed 35.50 percent of Papua's GRDP and the economic growth reaches 13.10 percent in 2016. However, most of the Mining and Quarrying in Papua was controlled by foreign companies such as PT. Freeport from the United States. Other sectors that experienced high growth 
were Electricity, Gas Procurement, Government Administration, Defense, and Compulsory Social Security sectors. Then, East Kalimantan Province had the lowest economic growth at 0.04 percent, far from the national economic growth, which was at 5.03 percent. This low economic growth was presumably due to a decline in the performance of several business sectors in the fourth quarter of 2016 (y-on-y) which had resulted in meaningless economic growth of several other business fields. Business fields that experienced a decline in performance in the fourth quarter of 2016 (y-on-y) were Mining and Quarrying, Construction, Government Administration, Business Activities, Real Estate Activities, and Financial and Insurance Activities. The mining sector experienced an economic slowdown of 3.52 percent with a decrease of IDR 7.76 trillion (Statistics Indonesia, 2017).

\subsubsection{General Overview of Poverty in Indonesia in 2016}

Poverty is one of the most basic issues of concern in any region, including Indonesia. High and low poverty is an indicator of development planning related to community welfare. The number of poor people in Indonesia has decreased by 587.4 thousand people from 28.6 million in 2015 to 28 million in 2016 after two periods of increase in the number of poor people, namely in 2014 and 2015. However, the decline in the number of poor people is not as big as the decline before the 2014 period. Although the number of poor people has declined, the number of poor people in Indonesia is not evenly distributed. Poverty for provinces in the eastern region of Indonesia shows a much greater number compared to most provinces in the western region of Indonesia which have a poverty rate of less than 10 percent. While the provinces with the highest percentage of poor people are Papua, West Papua and East Nusa Tenggara with a poverty rate of more than 20 percent, far above the national poverty rate of 10.86 percent.

From the information about the percentage of poor people in Indonesia, it can be seen that there is an unequal level of poverty in Indonesia. This inequality can be caused by among others, the uneven development in Indonesia. This is indicated by the high economy and infrastructure development centered on Java, specifically. Therefore, the government is curren- $+65+\quad$ *tly working to develop equitable development including infrastructure and investment development. Apart from inter-provinces, poverty inequality also occurs between urban and rural areas. Based on Table 2, poverty is more concentrated in rural areas. In terms of both the number and percentage of poor people, rural areas have greater value. Changes in numbers and percentages for urban areas are greater than in rural areas, meaning that decreasing poverty in urban areas runs faster.

Table 2. Number, percentage, and change of the poor according to regions in 2016

\begin{tabular}{llc}
\hline \multirow{2}{*}{ The year 2016 } & \multicolumn{2}{c}{ Regions } \\
\cline { 2 - 3 } & Rural & Urban \\
\hline Number of poor people (million people) & 17,67 & 10,34 \\
Percentage of poor people (\%) & 14,11 & 7,79 \\
Change of poor people number (\%) & $-1,53$ & $-2,94$ \\
Change of poor people percentage (\%) & $-0,70$ & $-6,03$ \\
\hline
\end{tabular}

Source: Statistics Indonesia 
Jurnal Ekonomi Pembangunan: Kajian Masalah Ekonomi dan Pembangunan, 21 (1), 2020, 47-59

\subsubsection{General Overview of Environmental Quality Index (EQI) in Indonesia in 2016}

The Environmental Quality Index (EQI) is a parameter compiled by the Ministry of Environment and Forestry and is one of the indicators used to measure the quality of the environment in Indonesia. The Ministry of Environment and Forestry reclassified the quality of the environment into 6 groups, namely very good (EQI $>80)$, good $(70<\mathrm{EQI} \leq 80)$, good enough $(60<\mathrm{EQI} \leq 70)$, not good $(50 \leq \mathrm{EQI} \leq 60)$, very poor $(40 \leq \mathrm{EQI}>50)$, and alert $(30 \leq \mathrm{EQI}>40)$.

Based on the EQI classification, Indonesia is classified as good enough with a value of 65.73 . From Table 3, it can be seen that the province that has the highest environmental quality is West Papua followed by the provinces of Papua, East Kalimantan, Southeast Sulawesi (Sultra/ Sulawesi Tenggara), Central Kalimantan (Kalteng/Kalimantan Tengah), and Aceh. With two of the provinces having very good environmental status, namely West Papua (83.01) and Papua (81.35). Others are included in the good category. On the other hand, the provinces that have the lowest quality index are DKI Jakarta, followed by DI Yogyakarta, West Java, West Nusa Tenggara, Riau, and Central Java. Of these provinces, only DKI Jakarta is on alert, with EQI values of 38.69 , while other provinces are in poor status.

Although the EQI nationally is in a good enough condition, based on the EQI calculation in Table 4, nationally in 2016 the EQI decreased by 2.50 points compared to 2015 , from 68.23 to 65.73. This decline was influenced by a decrease in the value of the Water Quality Index (WQI) of 5.48 compared to 2015 , from 65.86 to 60.38 . In addition to the other index WQI also experienced a decline namely, the Air Quality Index (AQI) fell by 2.23 points and the Land Cover Quality Index (LCQI) by 0.47 points. The portion of the decrease in EQI value of each component is $66 \%$ of WQI, $27 \%$ of AQI and 7\% of LCQI.

Table 3. EQI of several provinces in 2016

\begin{tabular}{lclc}
\hline \multicolumn{1}{c}{ The Lowest EQI } & \multicolumn{2}{c}{ The Highest EQI } \\
\hline \multicolumn{1}{c}{ Province } & EQI & \multicolumn{1}{c}{ Province } & EQI \\
\hline DKI Jakarta & 38.69 & Papua Barat & 83.01 \\
DI Yogyakarta & 51.37 & Papua & 81.35 \\
Jawa Barat & 51.87 & Kalimantan Timur & 76.85 \\
Nusa Tenggara Barat & 56.53 & Sulawesi Tenggara & 75.24 \\
Riau & 56.73 & Kalimantan Tengah & 74.71 \\
Jawa Tengah & 58.75 & Aceh & 73.55 \\
\hline
\end{tabular}

Source: Ministry of Environment and Forestry (2017)

Table 4. Change of EQI in the year 2015-2016

\begin{tabular}{cccc}
\hline Index & $\begin{array}{c}\text { The year } \\
\mathbf{2 0 1 5}\end{array}$ & $\begin{array}{c}\text { The year } \\
\mathbf{2 0 1 6}\end{array}$ & The Change \\
\hline $\mathbf{( 1 )}$ & $\mathbf{( 2 )}$ & $\mathbf{( 3 )}$ & $\mathbf{( 4 )}$ \\
\hline EQI & 68,23 & 65,73 & $-2,50$ \\
WQI & 65,86 & 60,38 & $-5,48$ \\
AQI & 83,84 & 81,61 & $-2,23$ \\
LCQI & 58,30 & 57,83 & $-0,47$ \\
\hline
\end{tabular}

Source: Ministry of Environment and Forestry (2017) 
The biggest decrease in the value of WQI was experienced by West Java (Jawa Barat) province with its contribution to the decline in the national WQI is $77.95 \%$. The drastic decline experienced by West Java is due to an increase in water quality parameters (KLHK, 2017). In general, the Ministry of Environment and Forestry revealed that the potential factors that affect the quality of the environment in West Java are due to an increase in waste, both solid and liquid waste from industrial activities, agriculture and livestock, even the Hazardous and Toxic Material waste from lodgings and hospitals. This condition is worsened by the limited defecation facilities owned by residents of West Java and landfill. The three components of EQI, namely WQI, AQI, and LCQI show different patterns in each province. However, there are provinces that experienced a decline in the three components, namely Aceh, North Sumatra, Bengkulu, Lampung, Central Java, West Kalimantan, Central Sulawesi, West Sulawesi, and North Maluku. While another province experienced an increase for the three components, namely Banten Province, 23 other provinces experienced a decline in 1-2 categories and increases in other categories. In general, there are 12 provinces that experienced an increase in EQI and 21 other provinces experienced a decline in EQI.

\subsection{Discussion}

\subsubsection{Estimation of Path Coefficients Based on $1^{\text {st }}$ Structural Equation}

The first structural equation is used to see the effect of economic growth on changes in the number of poor people. From the results of processing, the structural equation is obtained and a summary of statistics is in Table 5.

The results of this study indicate that economic growth does not significantly affect directly the growth of the poor at a 5 percent significance level. Based on these results, there are indications that economic growth has not been able to directly reduce poverty which has been revealed by (Piotrowska, 2016). Even with the direction of the coefficients showing positive values, there are indications that an increase in economic growth will increase the growth of the number of poor people. Alleged economic growth has an indirect influence on poverty through variables such as unemployment, employment, and salary levels. In accordance with the research of Piotrowska (2016), economic growth has an effect on poverty reduction through redistribution of income and labor market, namely an increase in labor absorption and an increase in wages. In addition, economic growth has not been able to reduce poverty because of other factors that are more dominant such as controlled population rates and human capital accumulation (Siregar, 2010). In addition, income inequality is one of the causes of economic growth has not been able to directly reduce poverty (Suhartini, 2011).

One of the measures used to show income inequality is the Gini coefficient. Based on BPSStatistics Indonesia data for 2016, six provinces namely Papua, South Sulawesi (Sulawesi Selatan), West Nusa Tenggara (Nusa Tenggara Barat), West Java (Jawa Barat), East Java (Jawa Timur), and Central Java (Jawa Tengah), each have a Gini coefficient greater than 0.35 . This means that income inequality in those provinces are relatively unequal if it is based on the classification (Todar et al., 2011). The existence of income inequality is thought to be an obstacle to reducing poverty in Indonesia in 2016. There is a positive relationship between income inequality and poverty (Wodon, 1999"mendeley":\{“formattedCitation”:"(Wodon, 1999; Hajiji, 2010). Income inequality that is as an obstacle to poverty reduction (Siregar, 2010) that in any development characterized by economic growth should be in line with the decline in income inequality in order to be effectively reducing poverty. Economic growth with relatively unequal income distribution conditions indicates that economic growth is only felt by the upper layers of society. Income inequality that occurs in almost all developing countries is caused by uneven ownership of assets or wealth. The reason why the top 20 percent of the population often receives more than 50 percent of national income is because 20 percent of the population owns and controls more than 90 percent of productive and financial resources, namely physical capital, land, stocks, bonds and human capital in the form of better education and health (Todaro et al., 2011). 
Avalaible online at http://journals.ums.ac.id, Permalink/DOI: 10.23917/jep.v21i1.8262

Jurnal Ekonomi Pembangunan: Kajian Masalah Ekonomi dan Pembangunan, 21 (1), 2020, 47-59

Table 5. Summary of Statistical Estimation of $1^{\text {st }}$ Structural Equations

\begin{tabular}{|c|c|c|c|}
\hline Endogen Variable & Sig. & & \\
\hline PDRB_G & 0.691 & $\begin{array}{l}\text { R-squared } \\
\text { F-Statistics }\end{array}$ & $\begin{array}{l}0.005 \\
1.225\end{array}$ \\
\hline Assumption & Sig. & Decision & Conclusion \\
\hline Normality (Shapiro-Wilk test) & 0.18211 & Failed to reject $\mathrm{H}_{0}$ & Normal \\
\hline Homoscedasticity (Glejser test) & 0.9601 & Failed to reject $\mathrm{H}_{0}$ & Homoscedasticity \\
\hline Non-autocorrelation (Durbin-Watson) & 0.1020 & Failed to reject $\mathrm{H}_{0}$ & Non-autocorrelation \\
\hline
\end{tabular}

Table 6. Summary of Statistical Estimation of $2^{\text {nd }}$ Structural Equations

\begin{tabular}{lcclc}
\hline Endogen Variable & Exogen Variable & Sig. & & \\
\hline RIKLH & PDRB_G & 0.487 & R-squared & 0.151 \\
& LnP0i & 0.032 & F-Statistics & 2.671 \\
\hline \multicolumn{1}{c}{ Assumption } & Sig. & Decision & Conclusion \\
\hline Normality (Shapiro-Wilk test) & 0.08120 & Failed to reject $\mathrm{H}_{0}$ & Normal \\
Homoscedasticity (Glejser test) & 0.7061 & Failed to reject $\mathrm{H}_{0}$ & Homoscedasticity \\
Non-autocorrelation (Durbin-Watson) & 0.3499 & Failed to reject $\mathrm{H}_{0}$ & Non-autocorrelation \\
Non-multicollinearity(VIF = 1,005) & - & - & Non- multicollinearity \\
\hline
\end{tabular}

From the results of the study, it can be concluded that economic growth cannot directly affect the decline in poverty (Piotrowska, 2016), and the direction of a positive relationship between economic growth and poverty. Therefore, a policy which leads to indirect poverty reduction is needed, namely through a decrease in income inequality and unemployment and an increase in human capital. For example, a policy that encourages the poor to improve their abilities so that they can participate in economic activities in the context of economic development (Sumargo \& Titin, 2009).

\subsubsection{Estimation of Path Coefficients Based on $2^{\text {nd }}$ Structural Equations}

The second structural equation is used to see the effect of economic growth and the growth of the poor population on the quality of the environment. From the results of processing, the $2^{\text {nd }}$ structural equation is obtained and a summary of statistics is as in Table 6.

\subsubsection{Effect of Economic and Poor Popula-} tion Growth on Environmental Quality

The results of this study indicate that economic growth has no significant direct effect on environmental quality at a 5 percent significance level, with a positive direction of influence. The influence of economic growth on environmental quality according to the Environment Kuznets Curve (EKC) (Magnani, 2001) hypothesis can have negative or positive effects. Negative effects can occur when economic growth is generally driven by the process of industrialization because in the process of industrialization produces residuals which are then discharged into the environment causing a decline in environmental quality or environmental degradation. On the other hand, the positive effects of economic growth on environmental quality can occur when the economy is driven by the service sector which produces relatively little residual into the environment ( Thomas et al., 2000). 
Table 7. The contribution of Industry Sector in Indonesia in 2015-2016

\begin{tabular}{clcc}
\hline \multirow{2}{*}{ No. } & Industry & \multicolumn{2}{c}{ Contribution (\%) } \\
\cline { 3 - 4 } & & 2015 & 2016 \\
\hline 1. & Agriculture, Forestry, and Fishing & 21.14 & 20.65 \\
& Mining and Quarrying & & \\
2. & Manufacturing & 20.99 & 20.51 \\
3. & Service & 57.87 & 58.84 \\
\hline
\end{tabular}

Source: Statistics Indonesia

Table 8. Direct, indirect, and total effect of exogenous variables on endogenous variables

\begin{tabular}{llll}
\hline \multicolumn{1}{c}{ Variable } & \multicolumn{2}{c}{ Effect } & Total \\
\cline { 2 - 4 } & Direct & Indirect & \\
\hline Economic growth towards poverty & - & \\
$\begin{array}{l}\text { Economic growth towards environmental } \\
\text { quality }\end{array}$ & $(0,027)^{*}(-0,379)=-0,010$ & $0,119-0,010=0,109$ \\
Poverty towards environmental quality & - & \\
\hline
\end{tabular}

The direction of a positive relationship between economic growth and environmental quality can be shown in Table 7 which contains Indonesia's Gross Domestic Product during 2016 where Indonesia's GDP is dominated by the service sector. From 2015 to 2016, the Indonesian economy showed a decrease in the contribution of the agriculture and processing industries, while the services sector experienced an increase. Then, the growth rate of the agricultural sector and the processing industry experienced a slowdown during 2016 compared to 2015 (Thomas et al., 2000).

Residues caused by agricultural and livestock activities include total phosphate (which comes from fertilizer), methane, $\mathrm{NO}_{2}$, TSS. These activities can also affect the surrounding BOD and COD. While the industrial sector emits residues, especially TSS, NO2, and BOD and COD. Some of these residuals are indicators for knowing water and air quality. With the decline in the contribution and growth of the agricultural, mining and processing industries that emit various environmental pollutants residues show a positive relationship between the growth of the sector and the quality of the environment.

On the other hand, the contribution of the forestry sector also declined compared to 2015, with the forestry sector growth rate of $-1.21 \%$. Furthermore, the Ministry of Environment and Forestry in the 2016 EQI publication stated that the decline in the value of the land cover index was estimated, among others due to land clearing activities, forest/land fires, illegal logging, usage of forest areas for sectors outside forestry, unlicensed mining, and settlements. Thus, the results of a study that states that there is no significant influence on the positive direction of economic growth can be due to the decline in the contribution of the agricultural sector and processing industry which play a role as a contributor to the environment with a small decrease and other factors outside of economic activity.

Education and environmental quality have a relationship- poor people tend not to know the limitations and consequences of exploiting natural resources (Jodha, 1998). One way to get this knowledge is through education. Unfortunately, education for the poor is at a low level, most of the poor have an education level below high school. Based on BPS, about more than 75 percent of the poor have less education than high school. Poor people who have low education have a low chance of working in the formal sector. With the encouragement to meet the needs of 
life, poor people with low education are forced to work in the informal sector which depends on natural resources and the environment. With low education and high dependence on natural resources and environment, resulting in exploitation that is not environmentally friendly, causing damage to nature. Education on environmental health (environmentally friendly) is needed in order to achieve sustainable development (Sumargo et al., 2018). Therefore, there is a need for quality, environmentallyconscious education and training for the poor, and also coupled with the creation of business fields that are able to absorb a large workforce. Based on the result of data processing, direct, indirect, and total effects is as in Table 8.

The government needs to work for progrowth economic development indeed, but the income equalization which comes from progrowth development is also important so that development can also be felt by the poor population (pro-poor). Some of the pro-poor policies include: (1). Providing assistance to the poor in the form of additional skills by intensifying skills training activities for them to have entrepreneurial skills and opportunities to obtain business capital so that they can participate in economic activities; (2). Providing opportunities for the poor to have good basic and advanced education in order to have equal skills so that they are expected to have equal opportunities in finding work. The provision of free education assistance to the poor must be accompanied by updated data on the poor recipients so that assistance can be on target; and (3). Providing assistance to the economic sector that directly or indirectly touches the lives of most of the lives of the poor such as agriculture, fisheries, small and medium enterprises, and informal workers. Dasgupta and Symlieh (2006) remarked a positive relationship between rural poverty, fertility and degradation of environmental resources.

The assistance can be in the form of organic fertilizer subsidies, protection to farmers from bonded practice, advanced and environmentally friendly agricultural education or training. In addition, the right policies to improve environmental quality due to poverty has a negative effect on environmental quality include: (1). Build a number of low-cost housing units that are habitable such as flats to be able to be reached by the poor, especially in urban areas; (2). Increasing activities that disseminate education about the environment, for example, counseling on environment awareness; (3). Improve the controlling of mining activities that are over-exploiting and without environmental remediation, for example, public mining/people's mining.

Besides, several policies to improve the environmental quality related to economic growth include: (1). Improve controlling on economic activities which are related to the use of natural resources and the environment, whether new companies or those that have long been operating, periodically; (2). Take action on business entities that violate the safe boundaries of environmental pollution and other requirements firmly, such as fines for high remediation or threat of dismissal of operations on economic activities carried out by that business; and (3). Reviewing the requirements of an agency or business in the establishment of economic activity areas involving natural resources and the environment. With the insignificant direct influence of economic growth on poverty, further research can use other variables which will become intermediate/ interventions variables between economic growth to the decreasing of poor people. Then, when EQI already has a long series, the research can use other methods to be able to see the comparison between spaces at the same time between times.

\section{Conclusions}

The biggest problem related to environmental quality is a social problem namely poverty, especially in rural areas, this is indicated by existence: (1). Economic growth does not significantly affect poverty directly which the direction of the relationship is positive, this shows that economic growth in Indonesia in 2016 has no direct influence on poverty reduction. It is suspect 
that economic growth has an indirect influence on poverty, namely through variables such as unemployment, employment, and salaries and other variables such as income inequality; (2). Economic growth has no direct and indirect effect significantly on the quality of the environment with the direction of the relationship is positive, this shows that the economic growth that occurred in Indonesia in 2016 did not have a direct or indirect effect on the degradation of environmental quality as hypothesized. With a positive direction, there are indications that economic growth is beginning to show an improvement effort in environmental quality; and (3). Poverty has directly affected on the quality of environment with negative direction, this shows that with all its limitations and in order to meet the living need of the poor people can directly reduce the quality of the environment through the exploitation of natural resources and environment that less eco-friendly. So that, poverty reduction policies should be prioritized in reducing the number of poor people in rural areas.

\section{References}

Adu, D. T., \& Denkyirah, E. K. (2017). Kasetsart Journal of Social Sciences Economic growth and environmental pollution in West Africa: Testing the Environmental Kuznets Curve hypothesis. Kasetsart Journal of Social Sciences, 8-15. https:// doi.org/10.1016/j.kjss.2017.12.008

Statistics Indonesia. (2017). Statistika Indonesia 2017. Jakarta: Badan Pusat Statistik.

Budiman, A. (1995). Teori Pembangunan Dunia Ketiga. Jakarta: PT. Gramedia Pustaka Utama.

Copeland, B. R., \& Taylor, M. S. (2004). Trade, Growth, and the Environment, Journal of Economic Literature, 42(1), 7-71.

Costantini, V. (2006). Sustainable development and human development: an integrated approach, Countries. Journal of Development Studies, 36(6), 1-24.
Dariah, A. R. (2007). Dampak Pertumbuhan Ekonomi Dan Kemiskinan Terhadap Degradasi Lingkungan Di Jawa Barat. Bogor: IPB Thesis Unpublished.

Dasgupta, J., \& Symlieh, H. J. J. (2006). Trends in tenure arrangements for forest and their implications for sustainable forest management: the need for a more unified regime. Understanding Forest Tenure in South and Southeast Asia: Forest Policy and Institutions Working Paper 14.

Everett, T., Ishwaran, M., Ansaloni, G. P., \& Rubin, A. (2010). Economic Growth and the Environment, Defra Evidence and Analysis Series 2. EconPapers. retrieved from https://mpra.ub.uni-muenchen.de/23585/ MPRA Paper No. 23585, posted 01 Jul 2010 00:37 UTC

Ministry of Finance. (2018). APBN 2018. Jakarta: Kementerian Keuangan

Hajiji, A. (2010). Ketimpangan, Pendapatan, dan Pengentasan IPB: Thesis Unpublished

Hastuti. (2007). Pengentasan Kemiskinan dan Pembangunan Berwawasan Lingkungan. Yogya: UNY Working Paper Unpublished.

Hopwood, B., Mellor, M., \& Brien, G. O. (2005). Sustainable Development: Mapping Different Approaches. Sustainable Development Sust. Dev. 13, 38-52. DOI: $10.1002 /$ sd.244

Jodha, N. S. (1998). Natural Resource Management and Poverty Alleviation in Mountain Areas:

Approaches and Efforts. Nepal: ICIMOD Working Paper

Klasen, S. (2000). Measuring poverty and deprivation in south africa. Review of Income and Wealth, 46(1), 33-58.

(Ministry of Environment and Forestry. (2017). Statistik Lingkungan Hidup dan Kehutanan 2016. Jakarta, Indonesia.

Magnani, E. (2001). The Environmental Kuznets 
Curve: Development path or policy result? Environmental Modelling and Software, 16(2), 157-165. https://doi.org/10.1016/ S1364-8152(00)00079-7

Oktavilia, S., Puspita, D. W., \& Sugiyanto, F. X. (2018). The Relationship Between Environmental Degradation , Poverty and Human Quality in Indonesia. E3S Web of Conferences 73 , 10020 (2018) ICENIS 2018 Https://Doi.Org/10.1051/ E3sconf/201873100 20

Piotrowska, M. (2016). The Direct and Indirect Effects of the Pro-Poor Growth. Buletin Ekonomi Moneter Dan Perbankan, 18(3), 251-280.

Pratomo, D., \& Sumargo, B. (2017). Sebuah Alternatif: Better Life Index sebagai Ukuran Pembangunan Multidimensi di Indonesia. Jurnal Ekonomi dan Pembangunan Indonesia, 16(2), 123-140.

Ravallion, M., \& Chen, S. (2003). Measuring propoor growth. Economics Letters, 78, 93-99.

Rogers, P. P., Jalal, K. F., \& Boyd, J. A. (2008). An Introduction to Sustainable Development, 399-401. Sustainability: Science, Practice and Policy, 4(1), pp. 50-51 https://doi.org/1 0.1080/15487733.2008.11908015

Sahputra, M. (2014). Dilema Pertambangan Rakyat. Newspaper Articles.

Scherer, L., Behrens, P., Koning, A. De, Heijungs, R., Sprecher, B., \& Tukker, A. (2018). Trade-o ff $\mathrm{s}$ between social and environmental Sustainable Development Goals. Environmental Science and Policy, 90(September), 65-72. https://doi. org/10.1016/j.envsci.2018.10.002

Siregar, H, D. W. (2010). Dampak pertumbuhan ekonomi terhadap penurunan jumlah penduduk miskin. Bogor: IPB Thesis Unpublished.

Suhartini, A. M. (2011). Pro Poor Growth Tngkat Provinsi di Indonesia. Bogor: IPB Thesis Unpublished.
Sumargo, B., Kasuma, K. A. P., and Tsang Y.F. (2018). social-Environment as a Weak point of

Sustainable Development in Indonesia. AIP Conference Proceedings 2019, 030013 (2018); doi: 10.1063/1.5061866. View online: https://doi.org/10.1063/1.5061866

Sumargo, B., \& Novalia, T. (2018). Structural Equation Modelling for Determining Subjective Well-Being Factors of the Poor Children in Bad Environment. Procedia Computer Science, 135, 113-119. https:// doi.org/10.1016/j.procs.2018.08.156

Sumargo, B.,\& Titin. Y. (2009). Model Persamaan Struktural Pembangunan Manusia dalam kaitannya dengan Investasi sektor fisik, manusia, pendidikan, dan kesehatan di Indonesia. Jurnal Matstat, 9(2), Juli 2009. 108-117.

Todaro, M. P \& Smith, S. C. (2011). Pembangunan Ekonomi, Edisi Kesebelas, Jilid I. Jakarta: Penerbit Erlangga.

Thomas, V., Dailami, M., Dhareshwar, A., Kaufman, D., Kishor, N., Lopez, R., \& Wang, Y. (2000). The Quality of Growth. Jakarta : Gramedia Pustaka Utama,

Wodon. Q. (1999). Growth, Poverty, and Inequality: A Regional Panel for Bangladesh. Policy

Research Working Paper. The World Bank South Asia Region. Poverty Reduction and Economic Management Sector Unit. March 1999.

Zia, I. Z., \& Prasetyo, P. E. (2018). Analysis of Financial Inclusion Toward Poverty and Income Inequality, 19(1), 114-125. https:// doi.org/10.23917/jep.v19i1.5879 